\title{
Rozvíjanie relevantnej lexikálnej kompetencie u študentov medicíny na hodinách slovenčiny
}

\author{
Milota Haláková, Marína Kšiňanová
}

\begin{abstract}
Abstrakt: V príspevku vychádzame zo skúseností výučby slovenčiny na Lekárskej fakulte UK v Bratislave. Výučba slovenčiny je v tom to prostredí vnímaná predovšetkým ako prostriedok odbornej komunikácie pri štúdiu medicíny. Metódy rozvíjania relevantnej lexiky budeme prezentovat' prostredníctvom učebných materiálov z pripravovaných konverzačných učebníc: Slovenčina ako liek a Slovenčina ako diagnóza. Cielom príspevku je ukázat' praktické možnosti nadobúdania odborných lexikálnych kompetencií. Na slovo nepozeráme ako na samostatnú lexikálnu jednotku, slovo prezentujeme v kontexte a v danej situácii, kde nadobúda svoj špecifický význam. Naším zámerom je odhalit’ možnosti porozumenia významu slov na základe kontextu, ukázat' možnosti využitia slovotvornej motivácie, slovných asociácií a väzieb, zamerat' sa na vizuálnu pamät' študentov, prezentovat' možnosti situačného a komunikatívneho spôsobu učenia lexiky.
\end{abstract}

Kl'účové slová: relevantná lexika, slovenský jazyk, slovná zásoba, učebné materiály, učebnica, videá

\begin{abstract}
In the paper, we deal with the experience of tuition at the Faculty of Medicine, at Comenius University in Bratislava. The tuition of Slovak language is perceived mainly as the means of professional communication when studying medicine. The methods of developing relevant vocabulary will be presented through educational materials from conversational textbooks Slovak as a Remedy andSlovak as a Diagnosis. The goal of the paper is to present practical possibilities of developing professional lexical competencies. We do not see the word as a separate lexical unit, we present the word in the context and in the given situation where it takes on its specific meaning. We aim to reveal the possibilities of understanding the meaning of words based on context, to show the possibilities of using word-forming motivation, word associations, and links, to focus on students' visual memory, to present possibilities of the situational and communicative way of learning vocabulary.
\end{abstract}

Key words: educational materials, relevant lexis, Slovak language, textbooks, videos, vocabulary

\section{Úvod}

V príspevku sa zameriavame na rozvíjanie relevantnej lexikálnej kompetencie v rámci výučby slovenčiny ako cudzieho jazyka. Relevanciu vnímame ako „potrebu a užitočnost' osvojovania si lexiky podl'a cielov učiaceho sa“. (Liptáková, 2016, s. 175) Kedže ide o výučbu slovenčiny na lekárskej fakulte, cielom učiaceho sa je v našom prípade nadobudnút' predovšetkým komunikačné schopnosti pri konverzácii s pacientom a postupné osvojovanie si odbornej lekárskej terminológie. 
Metódy osvojovania si a rozvíjania slovnej zásoby budeme prakticky prezentovat' na základe pripravovaných konverzačných učebníc pre študentov medicíny pod názvami - Slovenčina ako liek a Slovenčina ako diagnóza. Najmä druhá čast' (Slovenčina ako diagnóza) bude venovaná osvojovaniu si relevantnej lexiky a rozvíjaniu komunikačných schopností učiaceho sa. Do výučby sa budeme snažit' implementovat' i prácu s videonahrávkami, ktoré sme vytvorili v spolupráci s odborníkmi v reálnom nemocničnom prostredí. Na základe nadobudnutých kompetencií učiaci sa (v našom prípade študenti lekárskej fakulty) využijú osvojenú lexiku pri tvorbe vlastných projektov.

\section{Metodológia}

V príspevku (ako i v spomínaných učebniciach) metodologicky vychádzame z kognitívnych psychodidaktických východísk. Opierame sa predovšetkým o metódu situačného komunikačného vyučovania britských lingvistov Harolda E. Palmera a A. S Hornbyho (Situational Languague Teaching) a čiastočne i o prirodzený prístup (The Natural Approach), ktorého tvorcami boli Tracy Terrell a Stephen Krashen. Ten je prezentovaný $\mathrm{v}$ našej učebnici hlavne formou vizualizácie slovnej zásoby. Snažíme sa preniest' reálny svet do učebne, využívame množstvo fotografií a autentických materiálov. Na rozdiel od spomínaného prirodzeného prístupu, pri ktorom je gramatika druhoradá, lexiku prezentujeme na podklade jej gramatického využitia. Lexika i gramatika sú pre nás rovnako dôležité. Súčastou vyučovania slovnej zásoby však zostáva i práca s textom. Slová nefigurujú ako samostatné lexikálne jednotky, študent si význam slov dedukuje na základe kontextu. Situácia je klúčovým zdrojom pre dekódovanie významu slov. Relevantná lexika je však vo forme odbornej terminológie často priamo vysvetlená. Zvyčajne je prezentovaná vo forme kolokácií a fráz, ktoré môže študent v lekárskej praxi použit'. Slovná zásoba je použitá na podklade sociálneho a kultúrneho pozadia. Pri prezentácii relevantnej lexiky sa zameriavame aj na budovanie a utvrdzovanie pamätových stôp študentov prostredníctvom osvojovania si asociačnej spätosti lexém. Vychádzame z lexikálnej paradigmy založenej na asociačnom a relačnom type budovania subjektívneho slovníka študenta. Lexikálna a gramatická náročnost’ textov sa takto postupne zvyšuje. Asociatívnost' sa spája s relevanciu, recyklovaním, primeraným tempom a opakovaním lexiky.

V príspevku (ako i v spomínaných učebniciach) vychádzame z nasledujúcich psycho-didaktických východísk:

1. Využite slovotvornej motivácie - vytváranie sémantických polí(rod, rodit', rodina)

2. Prezentácia slov v kontexte - dedukcia významu na základe kontextu

3. Vizualizácia slovnej zásoby - zameranie sa na vizuálnu pamätšstudentov 
4. Tvorba vlastnej slovnej zásoby podla individuálnej potreby študenta - tvorba mentálneho subjektívneho slovníka

5. Syntagmatické ukladanie lexiky vo forme slovných spojení a fráz

6. Usporiadanie lexiky na základe zvukovej blízkosti(raz - úraz, moc - moč)

7. Tvorba slovných asociácií a kolokácií - lex. jednotky vo vztahu koordinácie, subordinácie a negácie

8. Využitie možností situačného a komunikačného spôsobu učenia lexiky

9. Osvojovanie si odbornej lexiky prostredníctvom videonahrávok z nemocničného prostredia a inscenačných dialógov - rečová komunikácia, situačné zakotvenie komunikačných aktivít

10. Projektové vyučovanie

\section{Ciel'}

Cielom príspevku je ukázat' praktické možnosti nadobúdania lexikálnych kompetencií a poukázanie na inovatívne možnosti výučby relevantnej lexiky. Jazyk je vnímaný ako komunikačný prostriedok a sociálny fenomén.

\section{Využite slovotvornej motivácie}

Slovná zásoba je úzko spätá s gramatickou stavbou jazyka. Tvorenie slov a derivácia umožňujú študentom slovenčiny dekódovat’ lexikálne významy. Mechanické opakovanie lexiky sa mení na vizualizáciu slov, na odhalovanie významov na základe slovotvorne motivovanej lexikálnej zásoby. Slovotvorne motivované slová sa vyskytujú v slovenskom jazyku vel'mi často. „Podl'a zistenia, ktoré sa, pravdaže, pri bohatšom materiáli môže modifikovat', zastúpenie slovotvorne motivovaných slov v slovnej zásobe súčasnej spisovnej slovenčiny dosahuje asi 65 \%, t. j. takmer dve tretiny slovnej zásoby." (Furdík, 2004, s. 115). Hlavný podiel na tom majú slová tvorené deriváciou, predovšetkým sufixáciou a prefixáciou. $\mathrm{V}$ príspevku sa preto budeme d’alej zameriavat' predovšetkým na tvorbu slov pomocou sufixálnych a prefixálnych slovotvorných formantov. Popri osvojovaní si relevantnej slovnej zásoby slovenčiny, užitočnej pre študentov medicíny, sa budeme sústred'ovat' na pravdepodobne najfrekventovanejšie slová ich slovnej zásoby - liek a liečit'. Preto nám poslúžia ako motivanty. Vytvoríme usporiadaný súbor slov s tým istým koreňom (v našom prípade lek-, lieč-) a prepojíme ho vzájomnými motivačnými vzt’ahmi. Takto použité slová nebudú izolovanými jednotkami, budú motivačne späté. V komunikácii budú spĺňat' rôzne nominačné funkcie a budú schopné fungovat' v syntakticky rozdielnych konštrukciách. $\mathrm{V}$ texte pre začiatočníkov môžeme využit' spomínaný lexikálny motivant nasledujúcim spôsobom: 

Som medička. Študujem medicínu. Medicína je po slovensky lekárstvo, lekár- ska veda alebo liek. Latinsky mederi, medicare je po slovensky liečit'. Medicus je po slovensky lekár alebo lekárka. Medik je študent, ktorý študuje medicínu. Medička je študentka, ktorá študuje medicínu.
(latinsky loqui - rozprávat', hovorit' - magicky liečit')
lekár - lekárka, lekáreň, lekárnik - lekárnička, lekárnička (na lieky), liek, liečit' (lekár lieči pacienta), liečit’ sa (na čo) (pacient sa lieči na vysoký tlak), liečenie (pacient je chorý, potrebuje liečenie)

Novonadobudnuté slová sú prezentované študentom aj vizuálne pomocou predmetov a obrázkov. Tie môžu byt' využité konverzačne formou verbálnej deskripcie alebo narácie. Následne sú slová využité v cvičení, kde študent na základe správneho uchopenia sémantiky lexiky doplní adekvátne slovo do textu.

Pri pokročilejších znalostiach študentov môžeme zamerat' ich pozornost' na deriváciu, na prefixáciu a sufixáciu.

Sloveso liečit' (psl. lěčiti) je východiskovým motivantom. Opät’ vychádzame zo slovotvorného základu lieč-.

Slovotvorné predpony do-, pre-, vy- modifikujú význam slovesa.

Tab. 1: Slovotvorná motivácia

\begin{tabular}{|l|l|l|}
\hline & lieč- & it' \\
\hline do- & lieč- & it' \\
\hline pre- & lieč- & it' \\
\hline vy- & lieč- & it' \\
\hline
\end{tabular}

Predpona do- má v slovese doliečit' časový význam a tvorí sa ním sloveso s významom dokončenia deja. Predpona pre- v slovese preliečit' môže znamenat' vyplnenie určitého času danou činnostou, môže mat' však i význam - urobit' na iný spôsob ešte raz. Predpona $v y$ - v tomto prípade označuje pohyb von, odstránit', dat' von, dat' preč, dosiahnut' určitý stav. Z didaktického hl'adiska je poznanie významu prefixov výraznou pomôckou pre študenta slovenčiny. Umožňuje mu správne dekódovat' významy slov a zjednodušuje mu modifikáciu nových slov.

\section{Prezentácia slov v kontexte - dedukcia významu na základe kontextu}

Každú lekciu (kliniku) v úvode predstavuje tzv. klúčové slovo - rana (úrazy, nehody), moč (urologická klinika), rod (gynekologická klinika), trávit’ (gastroenterologická klinika), diet’a (pediatrická klinika), žit' (psychiatrická klinika), atd'. Toto slovo, prípadne koreň slova slúži ako základ pri tvorbe sémantických polí, ktoré 
sa študenti snažia analogicky tvorit’ na základe získaných gramatických a lexikálnych kompetencií. Týmto spôsobom si l’ahšie osvoja slovnú zásobu. Ako príklad asociačných väzieb môžeme uviest' použitie slovotvorného motivanta -trav. V tomto prípade vychádzame z krátkeho komunikačne zameraného textu. Text uvádza komunikačná otázka, ktorá otvára konverzáciu. Všetky motivované slová týkajúce sa relevantnej lexiky sú vyznačené kurzívou. Novú slovnú zásobu si študent sám dedukuje na základe kontextu. Subjektívny slovník si študent môže doplnit' na základe svojich individuálnych potrieb. $\mathrm{V}$ texte je vyznačený pod názvom: Aj toto potrebujem vediet'. Ako príklad uvádzame ukážku textu z kapitoly zameranej na gastroenterologické tažkosti.

AHOJTE!
Ako ste strávili víkend?
$\begin{aligned} & \text { Ja som strávila víkend trávením zlej stravy. Zjedla som niečo zlé } \\ & \text { a trávením. Bolo mi l'úto, že som strávila víkend v posteli } \\ & \text { stráviacimi problémami. Asi sa musím stravovat' zdravšie. Ale } \\ & \text { dnes je už lepšie. Trávenie sa mi zlepšilo a ja verím, že strávim } \\ & \text { pekný deň. Dúfam, že i vy }\end{aligned}$

\section{Syntagmatické ukladanie lexiky vo forme slovných spojení a fráz}

Tab. 2: Tvorba slovníka na základe slovotvornej motivácie

Kl'účové slovo: trávit'

\begin{tabular}{|l|l|l|l|l|}
\hline verb imp. & verb perf. & noun & adjective & noun - place \\
\hline trávit' & vytrávit' & trávenie & tráviaca (sústava) & gastroenterológia \\
\hline trávit' & otrávit' & otrava & otrávený & \\
\hline & & potraviny & $\begin{array}{l}\text { potravinová } \\
\text { (alergia) }\end{array}$ & \\
\hline $\begin{array}{l}\text { zlepšovat' } \\
\text { trávenie }\end{array}$ & $\begin{array}{l}\text { zlepšit' } \\
\text { trávenie }\end{array}$ & $\begin{array}{l}\text { zlepšovanie } \\
\text { trávenia }\end{array}$ & $\begin{array}{l}\text { zlepšené } \\
\text { trávenie }\end{array}$ & \\
\hline stravovat' sa & & $\begin{array}{l}\text { stravovanie } \\
\text { strava }\end{array}$ & $\begin{array}{l}\text { stravovacie } \\
\text { (návyky) }\end{array}$ & \\
\hline
\end{tabular}

ALE POZOR! Môžeme trávit' alebo strávit' aj čas (nie však peniaze).

\section{Vizualizácia slovnej zásoby}

Slovná zásoba je v učebnici Slovenčia ako liek vizualizovaná prostredníctvom rôznej farby šiat hlavnej postavy učebnice, zahraničnej študentky medicíny. Študentka Anne vystupuje v úlohe symbolu, piktogramu a reprezentuje lubovol'ného študenta lekárskej fakulty. Tematické zameranie lexiky je symbolicky farebne rozlíšené. Pri nadobúdaní bežnej každodennej lexiky, Anne dostáva modrú infúziu, pri 
Tab. 3: Tvorba subjektivneho slovníka

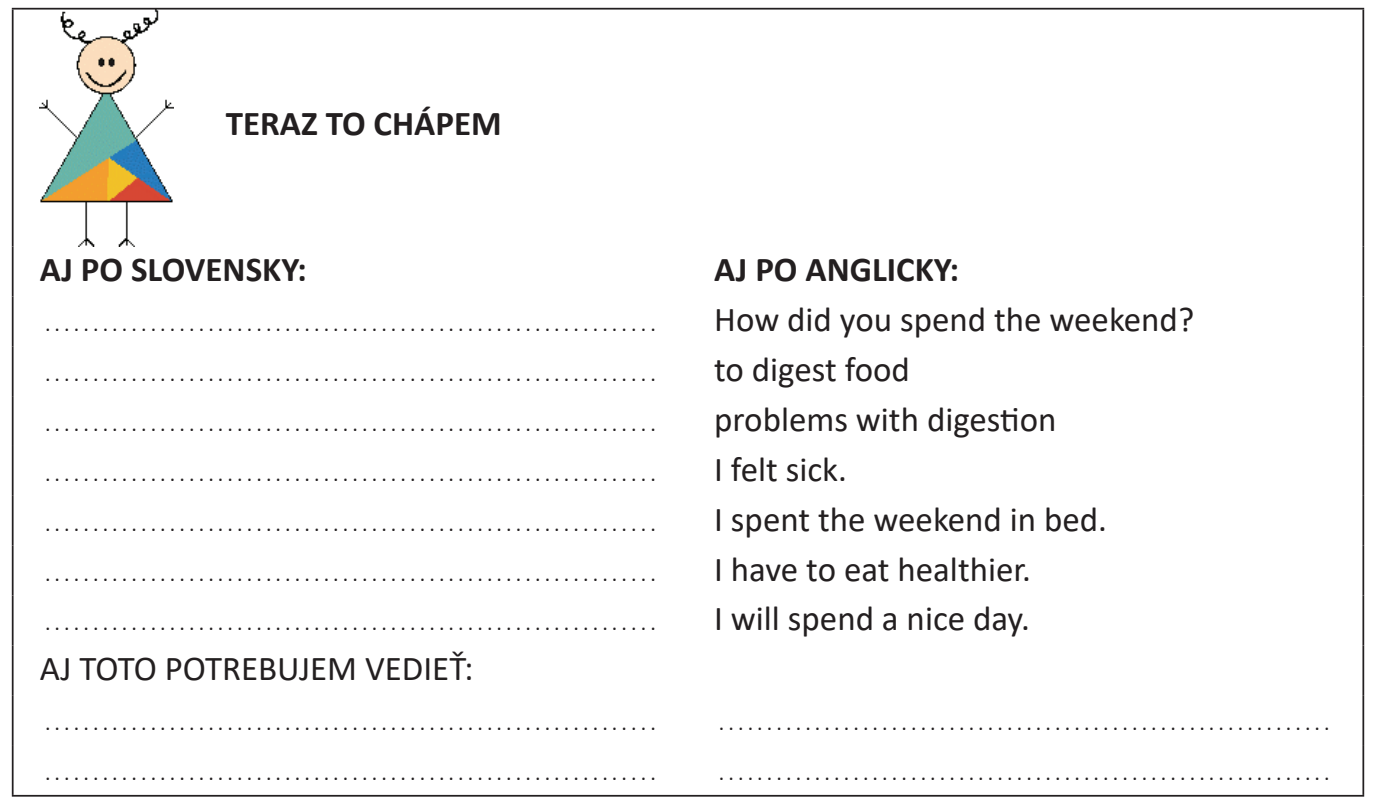

oddychu oranžovú, emocionálne zážitky reprezentuje červená a spoznávanie sociokultúrneho prostredia žltá farba. Relevantná lexika je symbolicky vyznačená zelenou farbou Anniných šiat. Anne má na sebe farebné šaty po absorbovaní základnej slovnej zásoby prvej učebnice. Učebnica Slovenčia ako diagnóza je zameraná na relevantnú lexiku, preto infúzie, ktoré dostáva sú len zelenej farby. Toto vizuálne rozlíšenie lexiky môže študentovi pomôct’ pri diferenciácii slovnej zásoby, l'ahšej orientácii, ako i pri vizuálnom ukladaní pamätových stôp.

\section{Využitie možností situačného a komunikačného spôsobu učenia lexiky}

Odborná terminológia je prezentovaná na základe konkrétnych kliník (kardiologická, urologická, chirurgická, psychiatrická, atd’) symbolicky znázornených na titulnej strane učebnice prostredníctvom infúzie. Relevantná lexika súvisiaca s danou klinikou je v tomto prípade podaná diferencovane a priamo. Vymedzené sú časti tela, orgány, choroby, príznaky (symptómy), lieky a liečba, vyšetrenia súvisiace s danou klinikou. Konkrétne a odborne sú zamerané i kazuistiky z danej kliniky. Po vypočutí kazuistiky študenti tvoria chorobopis. Na základe počutia doplňajú základné údaje do tabul'ky, ktorú si následne upravia a doplnia po prečítaní textu a po práci s ním.

Text kazuistiky nám poslúži aj na komunikačne zamerané cvičenia. Študent počas praxe v nemocnici musí klást' pacientom otázky týkajúce sa ich zdravotného stavu. Opakovaním podobných otázok sa študentove explicitne nadobudnuté znalosti 


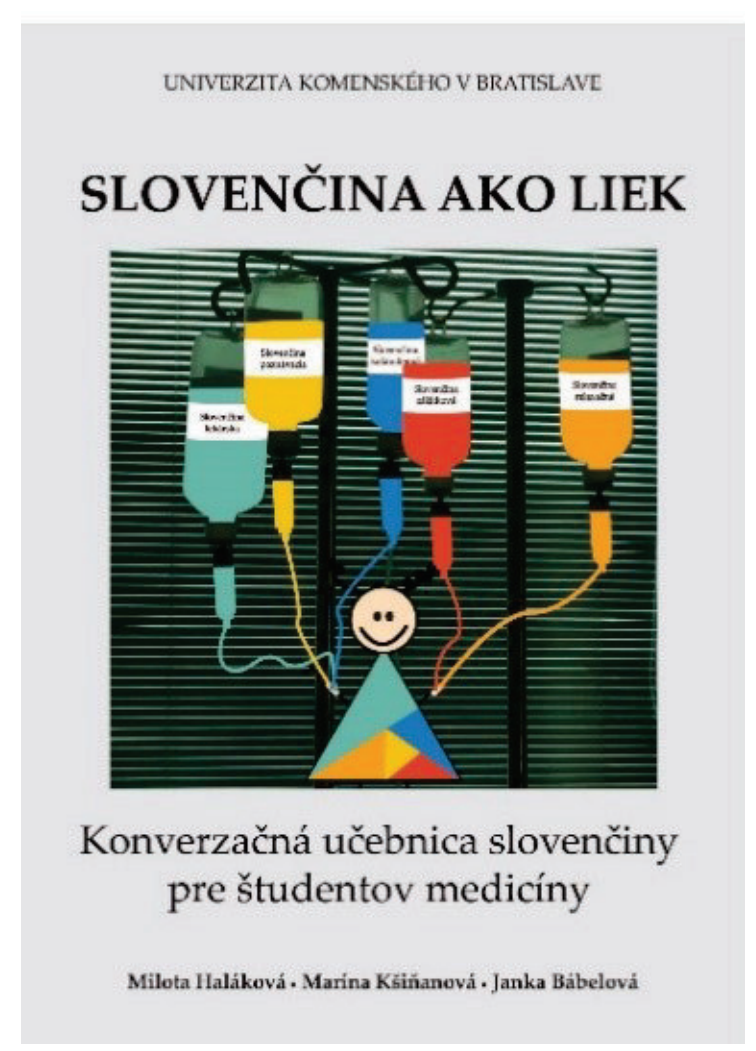

Obr. 1: Titulka učebnice Slovenčina ako liek
UNIVERZITA KOMENSKÉHO V BRATISLAVE

\section{SLOVENČINA AKO DIAGNÓZA}

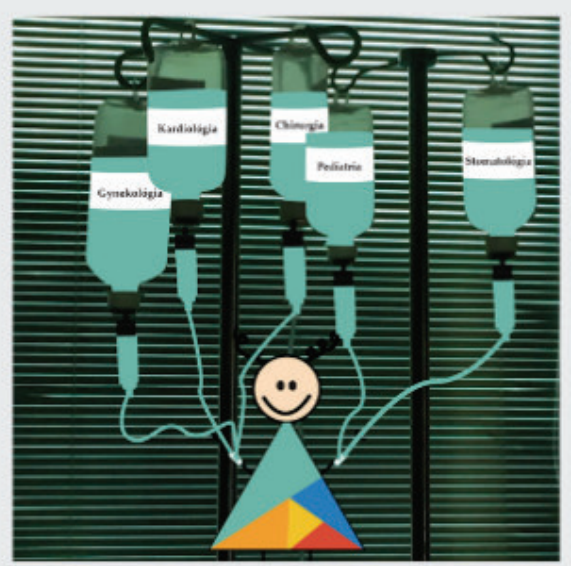

II. čast' konverzačnej učebnice SLOVENČINA AKO LIEK

Milota Haláková • Marína Kšinhanová • Janka Bábelová

Obr. 2: Titulná strana učebnice Slovenčina ako diagnóza

Tab. 4: Chorobopis pacienta

\begin{tabular}{|l|c|c|}
\cline { 2 - 3 } \multicolumn{1}{c|}{} & \multicolumn{1}{c|}{ ČO SOM POČUL/LA } & ČO SOM ČITAL/LA \\
\hline MENO & & \\
\hline VEK & & \\
\hline PRÁCA & & \\
\hline ŽIVOTNÝ ŠTÝL & & \\
\hline PROBLÉMY/SYMPTÓMY & & \\
\hline VYŠETRENIA & & \\
\hline DIAGNÓZA & & \\
\hline LIEČBA & & \\
\hline
\end{tabular}

dostávajú do roviny implicitných, jeho komunikácia s pacientom sa stáva prirodzenejšou, jazyk začína používat’ automaticky.

Ako príklad uvádzame krátku ukážku konverzačného cvičenia (JA - študent, P pacient).

Ste na praxi. Čo sa spýtate tohto pacienta?/Čo poviete tomuto pacientovi? 


\begin{tabular}{|c|c|}
\hline JA: & ? P: Mám 65 rokov. \\
\hline JA: & ? P: Som na dôchodku. \\
\hline JA: & $\begin{array}{l}\text { ? P: Moja mama ešte žije, môj otec už } \\
\text { nežije. }\end{array}$ \\
\hline $\begin{array}{l}\text { JA: } \\
\text { JA: }\end{array}$ & $\begin{array}{l}\text { ? P: Zomrel na rakovinu hrubého čreva. } \\
\text { ? P: Vážim } 98 \mathrm{~kg} \text { a meriam } 170 \mathrm{~cm} \text {. }\end{array}$ \\
\hline
\end{tabular}

Na základe uvedených odpovedí, vychádzajúcich z textu musí študent viest' konkrétny dialóg s pacientom, postupne sa zoznamuje s odbornou terminológiou, konkrétnymi t’ažkostami a chorobami pacientov. Tým získava nielen komunikatívne, ale aj odborné kompetencie.

\section{Tvorba slovných asociácií a kolokácií vo vzt’ahu koordinácie a subordinácie}

Každá lekcia odbornej časti učebnice je ukončená vytvorením asociačného sémantického pola týkajúceho sa daného oddelenia a s ním spojenej lexiky. Študent na podklade vlastných pamätových stôp vytvára vlastné sémantické pole s podtitulom k cvičeniu na základe otázky:

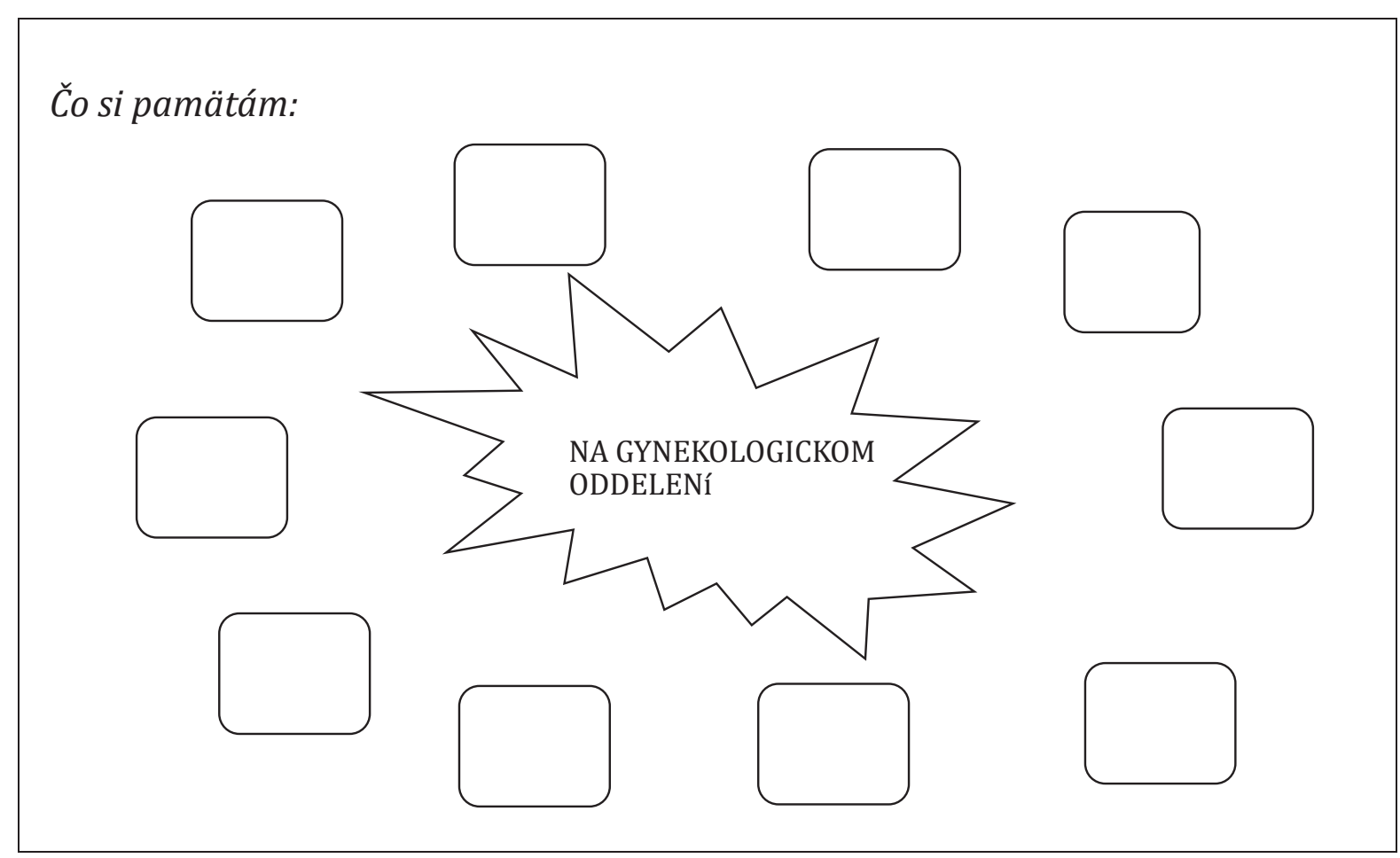




\section{Osvojovanie si odbornej lexiky prostredníctvom videonahrávok}

Súčastou našej publikácie sú aj videonahrávky, ktoré simulujú reálne prostredie lekárskych ambulancií. Videonahrávky vznikli v spolupráci s odborníkmi, tzn., že všetky dialógy boli vytvorené pod odborným dohladom. Vo väčšine videí vystupujú skutoční lekári, ktorí pre účely videa odoberajú anamnézu pacienta, ošetrujú poranenie, odborne vyšetrujú časti tela (abdominálnu oblast') alebo robia ultrazvuk. Vo videách prinášame dialógy z rôznych oddelení (napr. kardiológia, detská kardiológia, chirurgia, gynekológia, ORL, atd'.) a ponúkame l'ahšiu a t'ažšiu verziu. Lahšia verzia dialógu lekár - pacient je gramaticky a lexikálne prispôsobená tak, aby s ňou mohli pracovat' študenti na jazykovej úrovni A1/A2. Navyše, dialóg je jazykovo upravený a zameraný na konkrétny gramatický jav (napr. akuzatív, imperatív, lokál, minulý čas, inštrumentál, atd’), vd’aka čomu môžu študenti vidiet' použitie preberaného gramatického javu v reálnej komunikácii v lekárskom prostredí. $V$ tažšej verzii dialógu sme už nebrali do úvahy potrebu úpravy a zjednodušovania textu a študentom ponúkame text, $\mathrm{v}$ ktorom sú použité všetky pády a gramatické javy. Tieto dialógy sú určené študentom s jazykovou úrovňou A2/B1. Vzhladom na fakt, že v dialógoch (v lahšej aj tažšej verzii) je použitá všeobecná, ale aj špecifická odborná medicínska lexika, na začiatku dialógu majú študenti možnost' oboznámit' sa s novou lexikou v priloženom slovníku. Potom, ako si študent prečíta v slovníku nové slová a overí si ich anglický ekvivalent, učitel' pustí video jedenkrát. Podla úrovne študentov a ich porozumenia učitel' pustí video ešte raz a študenti bud' iba počúvajú, alebo si zároveň čítajú priložený prepis dialógu, kvôli lepšiemu porozumeniu.

Ako príklad uvádzame čast' textu z Kliniky popálenín, ktorý je určený pre jazykovú úroveň A1. Text je zameraný na imperatív.

(L: lekárka, J: pacientka Jana)

L: Cítite sa zle?

J: Áno, nie je mi dobre, bolí ma to.

L: Dajte si sako dole a sadnite si na vyšetrovací stôl.

J: Mám si lahnút'?

L: Nemusíte, dajte si nohy sem a otočte sa ku mne.

J: Tak je to dobre?

L: Dobre. Musím vám ranu vydezinfikovat' a ošetrit'. Nebojte sa! Máte na niečo alergiu?

J: Nie, nemám.

L: Moment, dám si sterilné rukavice. Nebojte sa, sed'te pokojne.

Po vypočutí dialógu majú študenti možnost' počúvat' text ešte raz so zameraním sa na detail. $\mathrm{K}$ dispozícii majú text s vynechanými slovami ( $\mathrm{v}$ tomto prípade formy 
imperatívu), ktoré dopíňajú do textu. Predpokladáme, že imperatív preberali už skôr na hodine. Pracovat' sa dá dvomi spôsobmi. Študenti bud' dopĺn̆ajú slová na základe kontextu, alebo počúvajú dialóg ešte raz a píšu, čo počujú.

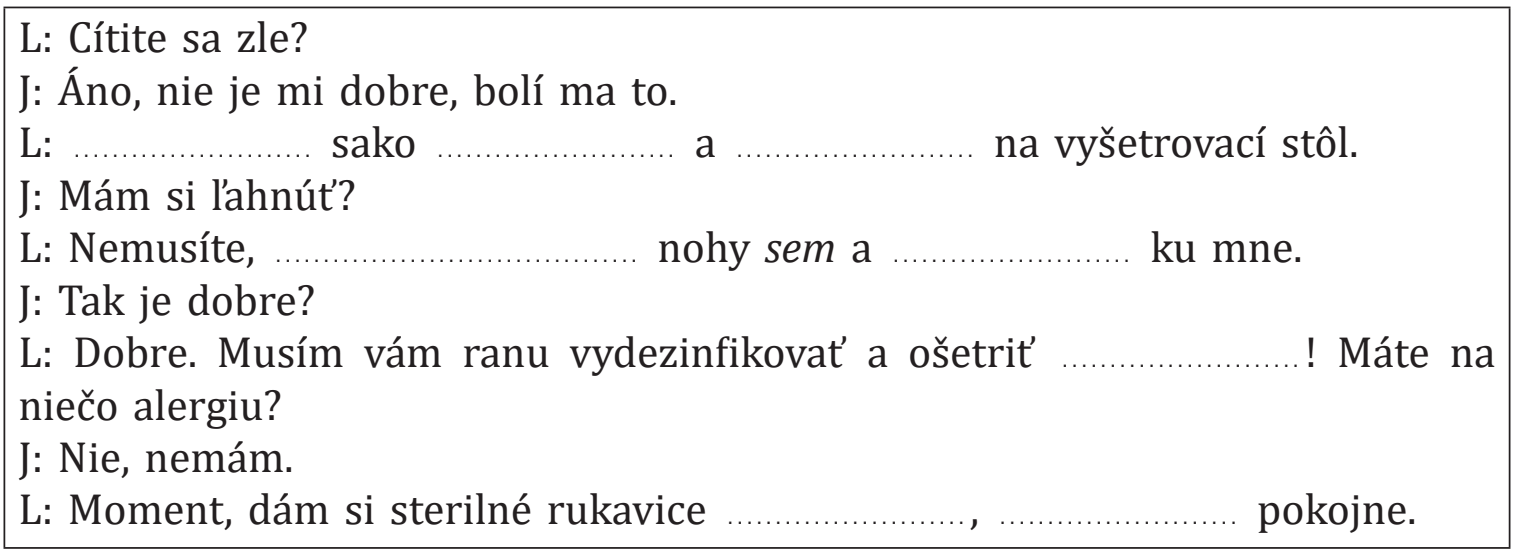

Po pozretí videa si učitel' môže zvolit’ z niekol'kých možností nadväzujúcej práce.

1. Študenti tvoria podobné dialógy inšpirované pôvodným dialógom.

2. Študenti sa snažia zapamätat' si pôvodný dialóg, ktorý si vo dvojici následne precvičujú.

3. Učitel' preloží jednotlivé repliky dialógu do jazyka študentov (v multikultúrnej triede to bude pravdepodobne angličtina), napíše ich na pásiky papiera. Úlohou študentov je preložit' ich do slovenčiny a dat' do správneho poradia. Môžu pracovat' v skupinách, dvojiciach či samostatne, podla úrovne triedy. Nakoniec si pozrú video a skontrolujú svoje preklady a správne poradie viet.

4. Študenti vytvoria vlastný dialóg, z ktoréhokolvek oddelenia či kliniky, naučia sa ho (ideálne naspamät'), nahrajú sa na mobilné zariadenie a video prezentujú pred celou triedou.

\section{Tvorba vlastných projektov a videí}

Je potrebné, aby si učitelia neustále kládli otázky: Čo chceme, aby sa študenti na hodine naučili? Ako na hodine rozvíjat' a učit' konkrétnu látku a zároveň vytvorit' priestor na rozvíjanie tzv. mäkkých zručností? Ako vytvorit' v triede priestor pre radost' a hravost'? Učitel' je ten, ktorý organizuje a manažuje či už prácu vo dvojici alebo prácu $\mathrm{v}$ skupinách, zadáva problémové úlohy a preskupuje študentov, aby dochádzalo k čo najlepšej a najčastejšej interakcii. Watts (In Cimermanová, 2016, s. 95) hovorí o prínosoch, ktoré prináša interakcia do tried.

1. Interakcia pomáha vytvárat' pocit komunity medzi študentmi, čo prispieva k ich spokojnosti, angažovanosti a intenzívnejšiemu učeniu (Brown, 2001). 
2. Interakcia prináša študentom spätnú väzbu, vd’aka ktorej zist'ujú, či sa im darí zvládat' a osvojovat' si vyučovací obsah.

3. Interakcia vystavuje študentov množstvu učebných zdrojov, vrátane skúseností a vedomostí ostatných študentov.

V našej praxi sa nám ako najvhodnejšie overilo práve tvorenie vlastných videí. Tvorba videí predstavuje akúsi syntézu gramatických, lexikálnych ale aj odborných vedomostí, ktoré študenti počas štúdia slovenčiny nadobudli. Ich úlohou nie je reprodukovat' už uvedené, ale vytvorit' niečo nové, pričom si v praxi overia, ako dokážu skombinovat' jazykové znalosti, gramatické ale aj odborné vedomosti do zmysluplného celku. Zároveň je dôležité podotknút', že na vytvorenie odborného dialógu lekár - pacient študent nie je sám. Je vítané, ak študenti pracujú vo dvojiciach či malých skupinkách, čo môže do tried vniest' viaceré pozitívne aspekty. Študenti sa vo dvojiciach či v kolektíve učia navzájom. Zdatnejší pomáhajú slabším, čo je prospešné pre obe strany, pretože je predpokladatelné, že ak sa študent dostane na istý čas do roly učitel'a, látku si lepšie zapamätá. Takéto učenie však prináša niečo ovel’a cennejšie. Prináša interpersonálne schopnosti, medziludský kontakt, vel'mi silný pocit partnerstva a súdržnosti, čo vytvára zo školy spoločenstvo. Hoci spoločnost' predpokladá, že jej jednotlivci budú vzájomne spolupracovat', pre mnohých táto požiadavka môže predstavovat' náročnú výzvu, kedž̌e k spolupráci neboli v škole vedení.

Inovatívne prístupy vo vyučovaní (projektové vyučovanie, konštruktivizmus, kooperatívne učenie, atd'), ktoré sú čoraz väčšou súčastou vyučovacieho procesu nielen v zahraničí, ale aj na Slovensku, prinášajú nový pohlad na učenie. Učenie už viac nepredstavuje mechanické osvojovanie vedomostí a zručností, ale „vštepovanie návykov s rozvojom schopnosti mysliet". (Kostrub, 2008, s. 32) „Ak sa teda mladý človek stane aktívnou súčast’ou vyučovacieho procesu, objem naučeného výrazne narastá. Najviac si však mladí l'udia zapamätajú, ak sú aktívne zapojení do činnosti a rozprávania, $z$ čoho si vedia zapamätat'v priemere 90 percent materiálu." (Trubačová, 2016, s. 402) Tvorba videí predstavuje spôsob, ako študent môže aktívne participovat' na svojom vzdelávaní, čo sa javí ako mimoriadne dôležité. Týmto spôsobom si študenti môžu vytvorit' „jasnú predstavu o svete a vnímat' veci z nadhladu." (Filo, Chomová a kol., 2017, s. 73) Bohatá základňa teoretických vedomostí slúži na pochopenie podstaty a prenos vedomostí. Prenesenie danej problematiky do praxe mení učenie na efektívnejšie, študent získava nadhl'ad a vie si tematiku spojit' s okolitým svetom.

\section{Záver}

V súčasnosti je spoločenské, pracovné a podnikatel'ské prostredie nastavené tak, že vyžaduje od jedinca vysokú mieru kreativity, vynaliezavosti, nezávislosti, tímovej spolupráce a flexibility pri riešení problémov. Mladý človek by sa mal i pro- 
stredníctvom štúdia na takýto svet pripravovat'. Vzdelávanie založené na poskytovaní faktov a informácií, na aktívnom prístupe učitel'a a pasívnom prístupe žiaka stráca svoju funkčnost', podobne ako aj memorovanie. Podla nášho názoru by pedagóg mal reflektovat' zmeny doby a brat' do úvahy potreby a záujmy študentov. Tímová spolupráca, kreativita, vzdelávanie orientované na študenta a podpora kritického myslenia by mali dominovat' v príprave na život. Aj preto zameranie sa na odbornost', relevantnost' a komunikatívnost' považujeme pri učení jazyka za klúčové. Práve relevantnú lexiku, osvojovanie si lekárskej odbornej terminológie a komunikáciu s pacientom považujeme za vhodný spôsob prípravy medikov na ich lekársku prax a neskorší profesijný život. Pri tvorbe našich učebných materiálov sme sa snažili o aktivizáciu študentov, o zohladnenie ich záujmov a potrieb, ako aj o vyvolanie emócií. Našou snahou bolo prebudit' v študentoch nielen záujem o jazyk, ale i o krajinu, v ktorej budú prežívat' svoje študentské roky. Veríme, že spomínané učebnice budú pre študentov a pedagógov nielen vhodnou odbornou pomôckou, ale prispejú i k vytvoreniu príjemného pracovného prostredia na hodinách slovenského jazyka.

\section{Učebnice:}

HALÁKovÁ, M., KŠIŇAnovÁ, M., BÁBELovÁ, J. (2019) Slovenčina ako liek. Univerzita Komenského, Bratislava. HALÁKovÁ, M., KšiŇAnovÁ, M., BÁBELová, J. (2019) Slovenčina ako diagnóza. (v tlači)

\section{Bibliografia}

DolníK, J. (2003). Lexikológia. Bratislava: Univerzita Komenského v Bratislave.

Cimermanové, I. (2016). E-learning in Higher Education. In: How to Teach in Higher Education. Dostupné z: https://www.researchgate.net/publication/311642282_E-LEARNING_IN_HIGHER_EDUCATION

Filo, P., \& Chomoví K. A KoL. (2017). Talentway\&Problem-based Learning. Bratislava: ABC - Academic Business Cluster.

FuRDík, J. (2004). Slovenská slovotvorba. Prešov: Náuka.

HALL, G. (2011). Exploring English Language Teaching, Language in Action. New York: Routledge.

HALÁKovÁ, M. (2017). Aplikácia teórie lexikálnej motivácie vo vyučovaní slovenčiny ako cudzieho jazyka na pozadí vnímania človeka ako prírodno-sociokultúrnej bytosti. In: Rebus linguae, 1 (s. 68-79). Ed. NIKOLAJOVÁ KuPFERSCHMIdTOVÁ, E. Bratislava: Comenius University in Bratislava, Faculty of Medicine.

HoRECKÝ, J. (1959). Slovotvorná sústava slovenčiny. Bratislava: Vydavatel'stvo SAV.

KAČALA, J. (1997). Kultúrne rozmery jazyka. Úvahy jazykovedy. Bratislava: Nadácia Korene, Univerzitná knižnica Bratislava.

Kostrub, D. (2008). Diet'a/žiak/student - učivo - učitel.' Didaktický alebo bermudský trojuholník? Prešov: Rokus.

KRÁLIK, L'. (2015). Stručný etymologický slovník slovenčiny. Bratislava: Veda, vydavatel'stvo SAV.

KuPKA, I. (2007). Jak úspěšne studovat cizí jazyky. Praha: Grada.

LıPTÁKovÁ, L'. (2016). Slovotvorná motivácia v slovenčine ako opora rozvíjania lexikálnej kompetencie cudzojazyčného študenta. In: Slovenčina (nielen) ako cudzí jazyk v súvislostiach II. (s. 165-183) Bratislava: Univerzita Komenského v Bratislave 
Lightbown, P. M., SPADA, N. (1997). Ako sa učíme jazyky. Bratislava: SAP.

LojovÁ, G. (2011). Individuálne osobitosti pri učení sa cudzích jazykov I. Bratislava: Univerzita Komenského.

MAJCHRÁKovÁ, D. A KOL. (2017). Slovník kolokácií prídavných mien v slovenčine, Bratislava: SAV.

NEBESKÁ, I. (1992). Úvod do psycholingvistiky. Praha: TOBOLA.

ORGoŇOvÁ, O. (2011). Lexika ako obraz kultúry etnika. In: Slovenčina (nielen) ako cudzí jazyk v súvislostiach. (s. 63-72). Ed. Pekarovičová, J., Hargašová, Z. Bratislava: Univerzita Komenského v Bratislave.

PetTy, G. (1996). Moderní vyučování. Praha: Portál.

REPKA, R. (1997). Od funkcií jazyka ku komunikatívnemu vyučovaniu. Bratislava: SAP.

RIES, L., \& KolÁRovÁ, E. (2004). Svet cudzích jazykov DNES. Bratislava: Pedagogické vydavatel'stvo DIDAKTIS.

Sokolová, M., \& OlošTiak, M., \& IvANovÁ, M. (2012). Slovník koreňových morfém slovenčiny. 3. upravené vydanie. Prešov: Vydavatel'stvo prešovskej university.

TiBEnSKÁ, E. (2016). Inovatívny prístup k vyučovaniu syntaxe slovenčiny ako cudzieho jazyka In: Slovenčina (nielen) ako cudzí jazyk v súvislostiach II. (s. 147-164). Ed. J. Pekarovičová, Z. Hargašová. Bratislava: Univerzita Komenského v Bratislave.

TRuBAčová, L. A. (2016). Vybrané metódy aktívneho vyučovania v kontexte slovenčiny ako cudzieho jazyka. In: Slovenčina (nielen) ako cudzí jazyk v súvislostiach II. (s. 400-419) Bratislava: Univerzita Komenského v Bratislave.

VAN WinkLE, R. A KOL. (2012). Active Teaching - Active Learning. Teaching Techniques and Tools. Dostupné z: https://catalog.extension.oregonstate.edu/sites/cataloq/files/project/pdf/4-h0259l.pdf

\section{Autorky}

Mgr. Milota Haláková, Lekárska fakulta Univerzity Komenského v Bratislave,

e-mail: milota.halakova@fmed.uniba.sk

Mgr. Milota Haláková ukončila štúdium na FFUK v roku 1989 s aprobáciou slovenský jazyk a literatúra a ruský jazyk a literatúra. V roku 1995 si rozšírila kvalifikáciu o anglický jazyk a literatúru. V rámci svojej dlhoročnej pedagogickej praxe sa venuje predovšetkým učeniu slovenčiny ako cudzieho jazyka. Na Lekárskej fakulte UK sa zaoberá inovatívnymi metódami učenia jazykov. Je spoluautorkou učebnice Slovenčina pre študentov medicíny (Ďurajka, R., Haláková, M., Jamrichová, V.) a jednou z autoriek konverzačnej učebnice slovenčiny pre medikov - Slovenčina ako liek (Haláková, M., Kšiňanová, M., Bábelová, J.). V súčasnosti pracuje s daným kolektívom autoriek na druhej časti spomínanej učebnice, ktorá bude zameraná na odbornú lekársku terminológiu a bude uvedená pod názvom Slovenčina ako diagnóza.

Mgr. Marína Kšiňanová, Lekárska fakulta Univerzity Komenského v Bratislave,

e-mail: marina.ksinanova@gmail.com

Mgr. Marína Kšiňanová pracuje na Lekárskej fakulte Univerzity Komenského. Študovala slovenský jazyk a anglický jazyk na Filozofickej fakulte Univerzity Komenského. Vo svojej praxi sa zaoberá inovatívnymi metódami, ktoré na hodinách aj úspešne aplikuje. V súčasnosti vyučuje anglický jazyk a slovenský jazyk pre cudzincov. Zároveň je v 3. ročníku PhD štúdia na Prešovskej univerzite v Prešove. Spolupracovala na tvorbe učebnice Slovenčina ako liek (Haláková, M.. Kšiňanová, M., Bábelová J.) a v súčasnosti sa podiel’a na tvorbe pripravovanej učebnice Slovenčina ako diagnóza. 